\title{
Photosynthetic Activity of Fodder Grasses Under Conditions of Drought Stress
}

\author{
Mariola Staniak* \\ Department of Forage Crop Production, Institute of Soil Science and Plant Cultivation-State Research Institute, Poland
}

*Corresponding author: Mariola Staniak, Department of Forage Crop Production, Institute of Soil Science and Plant Cultivation-State Research Institute, Poland.
Received Date: December 23, 2018

Published Date: January 09, 2019

\begin{abstract}
Crop performance is the results of genotypic expression modified by interaction with the environment. One of the environmental factors, that most widely limiting for the crop production is water. The deficit of water significantly limits the growth, development and yielding of crops. The paper presents a mini review of the own research results and the literature on the effect of water shortage on the rate of photosynthesis of forage grasses. A better understanding the physiological reactions of plants to water stress should improving irrigation efficiency, modifying plants for more efficient water use, and developing effective agriculture on dry area.
\end{abstract}

\section{Introduction}

The level of crop yielding depends strictly on the intensity of the photosynthesis process and is reduced by the loss of biomass resulting from respiration [1]. According to [2], nearly $90 \%$ of the accumulated biomass depends on the intensity of this process. Photosynthesis is one of the most important physiological processes, but at the same time one of the most sensitive to stress factors [3]. Mechanisms of coordination of photosynthesis and assimilates distribution processes in adverse environmental conditions are very complex and depend on the nature, intensity and duration of the stress factor [4]. Water deficiency in the soil may be such a factor. It is estimated that a $30 \%$ water deficit in the leaf is the limit above which the biochemical processes are significantly impaired [3]. The physiological age of the leaves and the size of the assimilation surface as well as the length of life and the ability of the leaf to effective photosynthesis are also very important. In the initial period of drought, the limitations of gas exchange in plants are mainly caused by the closing down of stomata. Only in conditions of prolonged stress there are disturbances in cellular metabolism [4]. In drought conditions, photosynthesis is inhibited, but the reaction of individual species and even varieties may be different. This depends on the degree of protoplast shrinkage during dehydration of cells, as well as the ability to efficiently reversible hydration, which is observed in drought-resistant plants [5]. Limitation of the intensity of photosynthesis caused by stress is most probably associated with a decrease in Rubisco activity and a decrease in the diffusion conductivity of the stomata, and thus a limitation of $\mathrm{CO}_{2}$ availability in extracellular spaces [6].

\section{Photosynthesis rate of grasses under drought stress}

The reduction in the intensity of photosynthesis in fodder grasses in drought conditions showed the results of own research and many authors. The [7] study showed a significant inhibition of this process in orchard grass (Dactylis glomerata), meadow fescue (Festuca pratensis), festulolium (Festulolium braunii) and Italian ryegrass (Lolium multiflorum) under long-term stress caused by water deficiency in the soil, but significantly less reduced intensity of this process in orchard grass and meadow fescue than Italian ryegrass and festulolium was shown, which indicates their greater resistance to stress. According to [8], the plant is resistant to stress if it is able to maintain physiological processes at the least changed level, in conditions different from the optimal ones. Therefore, the greater possibility of drought survival has those plants that have the ability to increase their tolerance to dehydration protoplast without disturbing its structure and vital functions. Also, the studies of [9] showed the smallest (statistically insignificant) decrease in photosynthesis intensity in conditions of drought stress in the orchard grass, while the greater (significant) in perennial ryegrass (Lolium perenne), timothy (Phleum pratense), tall oat grass (Arrhenatherum elatius) and meadow fescue. In turn, [10] showed a significant increase in photosynthetic intensity in the annual ryegrass (Lolium multiflorum var. westerwoldicum) grown 
in irrigated soil in a year characterized by shortage of rainfall in the growing season, which confirms its low resistance to drought.

The intensity of photosynthesis depends on many environmental factors, such as: type and intensity of light, temperature, concentration of oxygen and carbon dioxide in the air, water availability, but also on a number of internal factors such as leaf structure, chlorophyll content, enzyme activity, supply of mineral ingredients and plant development phase [3]. In the development of grasses, like other crop species, there are critical periods associated with greater sensitivity to water deficiency in the soil. In own studies [7], it was shown that with optimal soil moisture the studied grass species (orchard grass, meadow fescue, festulolium and Italian ryegrass) most intensively assimilated $\mathrm{CO} 2$ in late tillering, shooting and earing phases, while about $30 \%$ less in flowering stage. In drought conditions, the highest decrease in the intensity of this process was noted at the end of the vegetative phase and at the beginning of shooting, which means that during this period the tested species were the most sensitive to water deficiency in the soil. The age of plants was also very important in the resistance of fodder grasses to drought. In the first year of vegetation, all tested grass species showed greater resistance to stress than in the second and third year of vegetation. According to [11] water deficiency causes the accumulation of proline in plant cells, which is a substance with anti-stress effect. The rapid accumulation of this amino acid affects the better efficiency of water intake from the soil and allows it to be kept longer in the plant. According to [12] accumulation of proline depends on many factors, but one of the most important is the age of the plant, therefore young plants in drought conditions accumulate more proline than older plants, in subsequent years of vegetation.

\section{Conclusion}

Knowledge about the physiological and genetic basis of grass reaction to adverse environmental factors is insufficient. The changing climate and the increasingly frequent dry periods indicate the need to conduct research aimed at understanding the reactions of various fodder grass species to unfavorable environmental factors, which will enable their selection and proper choice of species for appropriate habitat and regional conditions.

\section{Acknowledgement}

None.

\section{Conflict of Interest}

No Conflict of Interest.

\section{References}

1. Olszewski J, Pszczolkowska A, Makowska M, Kulik T (2009) Effect of water deficit on gas exchange parameters, productivity and grain wholesomeness of spring wheat. Pol J Natural Sci 24(2): 85-92.

2. Lawlor D (1995) Photosynthesis, productivity and environment. J Exp Bot 46: 1449-1461.

3. Kalaji MH, Loboda T (2010) Fluorescencja chlorofilu w badaniach stanu fizjologicznego roslin. SGGW, Warszawa, pp. 116

4. Starck Z (2010) Effect of stress conditions on coordination of photosynthetic production and resources allocation. Post Nauk Rol 1: 9-26.

5. Starck Z (1995) Response of plants to unfavorable environmental conditions in aspects of source - sink relationships. Post Nauk Rol 3: 1935 .

6. Chaves MM, Oliveira MM (2004) Mechanisms underlying plant resilience to water deficits: prospects for water-saving agriculture. J Exp Bot 55(407): 2365-2384

7. Staniak M (2013) Response of selected species and cultivars of forage grass to water shortage in the soil. Mongr Rozpr Nauk 38: 1-217.

8. Dziadczyk P (2002) Genetic tolerance to abiotic stress in plants. Zesz Probl Post Nauk Rol 481: 49-60.

9. Olszewska M, Grzegorczyk S, Olszewski J, Baluch Malecka J (2010) A comparison of the response of selected grass species to water stress. Grassland Sci Pol 13: 127-136.

10. Rumasz Rudnicka E (2010) Wplyw nawadniania i nawożenia azotem na asymilację i transpirację zycicy westerwoldzkiej. Acta Agroph 15(2): 395-408.

11. Osorio ML, Osorio J, Vieira AC, Goncalves S, (2011) Influence of enhanced temperature on photosynthesis, photooxidative damage, and antioxidant strategies in Ceratonia silique L. seedlings subjected to water deficit and rewatering. Photosynthetica 49(1): 3-12.

12. Bandurska H, Gorny AG, Zielezinska M (2008) Effects of water deficit on the relative water content, proline accumulation and injury of cell membranes in leaves of old and modern cultivars of winter wheat. Zesz Probl Post Nauk Rol 524: 115-126. 